\title{
ANALISIS SISTEM INFORMASI AKUNTANSI PERSEDIAAN PELUMAS (STUDI KASUS PADA PT. FAJAR INDAH KUSUMA )
}

\author{
Andini Tirta Cricela Suleman ${ }^{1}$, Jantje J. Tinangon ${ }^{2}$, Winston Pontoh ${ }^{3}$ \\ 1,2,3 Jurusan Akuntansi, Fakultas Ekonomi dan Bisnis, Universitas Sam Ratulangi, J1. Kampus Unsrat, Manado, \\ 95115, Indonesia
}

E-mail : Andinisulaeman11@gmail.com

\begin{abstract}
Accounting Information System is an important thing owned by a company because the purpose and accounting information system is to provide information for users of accounting information that investors and other users inventory is one important component for a good company small and medium enterprises, and large companies. Because seen from the existing theory of inventory accounting information systems can provide many benefits for companies, especially PT. Fajar Indah Kusuma. The purpose of this study is to analyze whether the accounting information system inventory at PT. Fajar Indah Kusuma is adequate in the hope to provide benefits for the company, researchers and other parties. The method used in this research is the type of qualitative research that presents in the form of descriptive. While the data collection technique is done by direct survey to PT. Fajar Indah Kusuma and conducting interviews from several resource persons in the company. From the results of the study can be concluded that PT. Fajar Indah Kusuma not have adequate accounting information systems inventory where there are still short comings in the separator function dan internal control. The authors suggest that companies make impovements and evaluations on the system of divison of function and internal controls in order to run according to the system and efficient.
\end{abstract}

Keywords : Analysis, accounting information systems, inventory

\section{PENDAHULUAN}

Sistem informasi akuntansi merupakan hal penting yang dimiliki sebuah perusahaan karena tujuan dari sistem informasi akuntansi adalah menyediakan informasi bagi para pengguna informasi akuntansi yakni pemilik perusahaan, investor dan pengguna lainnya. Sistem informasi berkembang dari waktu ke waktu sehingga menyebabkan perubahan efektivitas dan efisiensi. Sistem informasi akuntansi yang efektif dan efisien diharapkan dapat memberikan informasi yang handal dan dapat menyediakan informasi yang berkualitas bagi pihak-pihak yang membutuhkan, harus bebas dari kesalahan-kesalahan, dan harus jelas maksud dan tujuannya. Untuk dapat menghasilkan informasi dengan karateristik tersebut, data yang diproses dalam system informasi akuntansi harus data yang benar dan akurat agar menghasilkan informasi yang dapat dipercaya.

Persediaan merupakan salah satu komponen penting untuk sebuah perusahaan baik perusahaan kecil, menengah, dan perusahaan besar ketika mereka menjalankan usahanya. Persediaan merupakan barang-barang yang dimiliki untuk kemudian dijual atau digunakan dalam proses produksi atau dipakai untuk keperluan non produksi dalam siklus kegiatan yang normal (Ester, 2013). Persediaan merupakan bagian utama dalam neraca dan seringkali merupakan perkiraan yang nilainya cukup besar yang melibatkan modal kerja yang besar. Tanpa adanya persediaan barang dagangan, perusahaan akan menghadapi resiko dimana pada suatu waktu tidak dapat memenuhi keinginan dari para pelanggannya. Tentu saja kenyataanya 
ini dapat berakibat buruk bagi perusahaan, karena secara tidak langsung perusahaan menjadi kehilangan kesempatan untuk memperoleh keuntungan yang seharusnya didapatkan.

Persediaan merupakan salah satu elemen terpenting dalam neraca, oleh karena itu dibutuhkan ketelitian yang ekstra dari segi pencatatan, penghitungan persediaan, penyimpanan persediaan serta berbagai perlakuan untuk mengelola persediaan yang ada agar terhindar dari kerugian yang disebabkan oleh kelalaian bahkan kecurangan. Menyadari hal tersebut, sebuah system akuntansi persediaan yang dirancang haruslah efektif dan efisien serta diharapkan dapat berjalan sesuai dengan tujuan.

Melihat teori yang ada bahwa sistem informasi akuntansi dapat memberikan banyak manfaat, maka penulis tertarik untuk meneliti dan mengetahui lebih jauh tentang bagaimana sistem informasi akuntansi yang diterapkan oleh PT. Fajar Indah Kusuma sebagai agen pelumas pertamina di Kabupaten Tolitoli Provinsi Sulawesi Tengah dalam mengontrol siklus Persediaan Pelumas yang ada serta akan mencoba membantu perusahaan untuk mengevaluasi Sistem Informasi Akuntansi dalam melihat kelebihan dan kekurangan yang ada, meliputi struktur organisasi, prosedur pendapatan, unit organisasi terkait, system otoritas, dokumen dan catatan akuntansi, serta bagan alir dokumen (flowchart) agar tertata dengan baik.

Berdasarkan uraian diatas maka penulis tertarik untuk menulis skripsi yang berjudul "Analisis Sistem Informasi Akuntansi Persediaan Pelumas (Studi Kasus pada PT. Fajar Indah Kusuma)".

\section{TINJAUAN PUSTAKA}

\subsection{Konsep Sistem Informasi Akuntansi} Pengertian Sistem Informasi Akuntansi

System informasi adalah system yang dibuat oleh manusia yang terdiri dari komponen-komponen dalam organisasi untuk mencapai suatu tujuan, yaitu untuk menyajikan informasi (Suryantara, 2014:4).

Menurut Jofiyanto, dikutip oleh Wower dan Widhiyani (2012), system informasi dapat dikatakan sebagai system dimana suatu organisasi mempertemukan kebutuhan pengolahan data transaksi harian, mendukung operasi, bersifat manajerial, dan kegiatan strategi suatu organisasi dan menyediakan kepada pihak luar tertentu laporan-laporan yang diperlukan.

Secara garis besar dapat dikatakan bahwa sistem informasi akuntansi merupakan sistem yang mengolah data transaksi keuangan menjadi laporan keuangan dengan menggunakan sistem informasi yang terhubung dengan jaringan komunikasi antara satu dengan bagian lainnya. Perkembangan ekonomi di Indonesia yang terjadi saat ini, menjadikan sistem informasi akuntansi sebagai suatu keharusan, karena sangatlah penting dalam pengambilan keputusan alokasi sumber daya fisik dan unsur-unsur untuk mengolah data ekonomi menjadi informasi akuntansi (SAR,2013).

\section{Tujuan Sistem Informasi Akuntansi}

Umumnya sistem akuntansi disusun untuk dapat memenuhi tiga macam tujuan yakni sebagai berikut :

1.Untuk meningkatkan kualitas informasi yang dihasilkan sistem, informasi, khususnya informasi akuntansi dianggap memiliki kualitas tinggi bila informasi yang bersangkutan relevan, tepat waktu, mempunyai daya banding, dapat diuji kebenarannya, mudah dimengerti dan lengkap.

2.Untuk meningkatkan pengendalian akuntansi dan cek internal, sistem akuntansi harus dapat memberi jaminan bahwa informasi akuntansi yang dihasilkan dapat diandalkan.

3.Untuk menekan biaya klerikal dalam menyelenggarakan catatan-catatan. 


\section{Siklus Proses Transaksi Sistem Informasi Akuntansi}

Pada sistem informasi akuntansi terdapat beberapa siklus yang ada didalamnya, salah satunya adalah siklus proses transaksi. Menurut Romney dan Steinbart (2012:28) yang diterjemakan oleh Dewi Fitria Sari dan Deni Arnos Kwary, siklus pemrosesan transaksi pada perusahaan dapat dibagi dalam lima subsistem yakni sebagai berikut:

1. Revenue Cycle, yang terdiri dari transaksi penjualan atau pendistribusian barang kepada entitas lain, pengiriman barang, penerimaan kas dalam bentuk tunai atau piutang tak ditagih, potongan tunai penjualan, return penjualan.

2. Expenditure cycle, yang terdiri dari peristiwa permintaan pembelian, pemesanan pembelian, penerimaan barang, pengeluaran kas dalam bentuk tunai atau kredit, potongan pembelian, dan sebagainya.

3. Human resource / Payroll cycle, yang terdiri dari peristiwa yang berhubungan dengan perekrutan, pembayaran atas tenaga kerja, pelatiah karyawan, promosi dan pemberhentian.

4. Production cycle, yang terdiri dari peristiwa yang berhubungan dengan pengubahan bahan mentah menjadi produk/jasa yang siap dipasarkan.

5. Financing cycle, yang terdiri dari peristiwa yang berhubungan dengan penerimaan modal dari investor dan kreditor dan membayar mereka kembali.

\section{Komponen dan Subsistem Sistem Informasi Akuntansi}

Menurut Puspitawati dan Anggadini (2011:59) “...Sistem Informasi terdiri dari 3 komponen utama, ketiga komponen sistem fungsi / subsistem adalah input, proses, outpus. Fungsi ini juga menunjukkan bahwa sistem sebagai proses tidak bisa berdiri sendiri, harus ada input, proses dan output".

\section{Unsur-unsur Sistem Informasi Akuntansi}

Menurut Sujawerni (2015:4), terdapat unsur-unsur dalam sistem informasi akuntansi yakni sebagai berikut :

1.Formulir adalah dokumen yang digunakan untuk mencatat terjadinya transaksi ekonomi di perusahaan.

2.Jurnal merupakan pencatatan berupa debet dan kredit yang bersumber dari formulir (dokumen dapat ditulis dalam secarik kertas untuk mendokumentasikan suatu transaksi ekonomi).

3.Buku Besar (general ledger) adalah akun-akun yang dikelompokkan dan berdasarkan akun yang telah dikelompokkan tersebut dilakukan penjumlahan nilai uangnya.

4.Buku Besar Pembantu (subsidiary ledger) adalah berfungsi untuk merinci akun yang ada di buku besar.

5.Laporan keuangan merupakan hasil akhir proses akuntansi. Laporan keuangan terdiri dari neraca, laporan rugi laba yang digunakan perusahaan untuk melakukan pengambilan keputusan guna mencapai tujuan perusahaan.

\section{Penggunaan Sistem Informasi Akuntansi}

Sistem informasi akuntansi ini secara umum digunakan untuk mengolah data transaksi keuangan yang terjadi dalam perusahaan. Dalam hal ini Sistem Informasi Akuntansi diharapkan dapat menghasilkan informasi yang dibutuhkan oleh perusahaan. Sistem Informasi Akuntansi memberikan dua informasi yaitu akuntansi historis dan peramalan yang meliputi akuntansi keuangan, kontrol manajemen dan analisis keuangan (Daoud dan Triki, 2013).

\section{Sistem Flowchart}

Sistem Flowchart adalah penyajian secara grafis dari sistem informasi dan sistem operasi yang terkait. Sistem informasi disini meliputi proses, aliran logis, input, output, dan arsip. 


\subsection{Konsep Sistem Informasi Akuntansi Persediaan Definisi Persediaan}

Persediaan merupakan istilah yang digunakan untuk menunjukkan barang-barang yang dimiliki oleh suatu perusahaan akan tergantung pada jenis usaha perusahaan.

\section{Jenis-jenis Persediaan}

Jenis persediaan di dalam perusahaan dagang, perusahaan industri, dan perusahaan jasa yang dikemukakan oleh Midjan La dan Susanto (2011:150) adalah :

1. Persediaan bahan baku

2. Persediaan barang dalam proses

3. Persediaan hasil jadi

4. Persediaan suku cadang

5. Persediaan bahan bakar

6. Persediaan barang cetakan dan alat tulis

7. Persediaan barang dagangan

\section{Sistem dan Prosedur Akuntansi Persediaan}

Sistem dan prosedur yang bersangkutan dengan sistem akuntansi persediaan dalam Sujawerni (2015:133) adalah sebagai berikut :

1. Prosedur Pencatatan Barang/Produk Jadi

a. Bagian Produksi

Prosedur yang terdapat dalam bagian produksi adalah sebagai berikut.

1). Bagian produksi membuat bukti Surat Pengiriman Barang Jadi (SPBJ) rangkap 3.

2). Bagian produksi menerima SPBJ lembar kedua dari bagian gudang.

b. Bagian Gudang

1). Bagian gudang menerima barang jadi dan SPBJ lembar ke 1 dari bagian produksi.

2). Setelah mengisi kartu gudang, bagian gudang meminta tanda tangan (untuk mengetahui produk jadi yang masuk ke bagian gudang) ke bagian akuntansi.

3). Berdasarkan kartu gudang yang telah ditanda tangani, bagian gudang membuat Surat Penerimaan Barang Jadi (SPBJ) rangkap 3.

c. Bagian Akuntansi

1).Bagian akuntansi menerima bukti SPBJ lembar ke-2 dari bagian produksi, kemudian diarsip untuk dijadikan bukti bahwa bagian produksi telah menyelesaikan produk jadi dan sudah melakukan pengiriman ke bagian akuntansi.

2).Bagian akuntansi menerima kartu gudang untuk ditandatangani sebagai bukti penerimaan barang jadi.

3).Bagian akuntansi menerima SPBJ lembar ke-1 dari bagian gudang.

4).Setelah mengisi kartu persediaan, bagian akuntansi mencatat di jurnal tentang persediaan barang jadi yang masuk.

d. Manajer

1).Manajer menerima laporan penerimaan barang jadi dari bagian akutansi.

2).Manajer juga menerima penyelesaian barang jadi dari barang produksi.

2. Prosedur Pencatatan Harga Pokok Produk Jadi yang Dijual

a. Bagian Produksi

1).Bagian produksi membuat surat permintaan bahan baku rangkap 2 .

2).Bagian produksi menerima surat pengiriman dan barang, lalu melakukan produksi.

3). Membuat laporan biaya bahan baku (DM), biaya tenaga kerja langsung (DL), dan biaya overhead pabrik (FOH) rangkap 2.

b. Bagian Gudang

1). Bagian gudang menerima surat permintaan barang bahan baku lalu mempersiapkan bahan baku yang diminta.

2). Membuat surat pengiriman barang rangkap 2. 
c.Bagian Akuntansi

1). Bagian akuntansi menerima laporan DM, DL, dan FOHL

2). Berdasarkan laporan tersebut bagian akuntansi menghitung DMC, DLC, dan FOH

3). Membuat laporan harga pokok produksi rangkap 2. Lembar ke-1 disimpan sebagai arsip dan lembar ke-2 dikirim ke manajer.

d. Manajer

1).Bagian manajer menerima laporan harga pokok produksi.

2).Berdasarkan laporan harga pokok produksi bagian manajer menentukan margin laba, lalu membuat laporan harga penjualan barang.

3. Prosedur Permintaan dan Pengeluaran Barang Gudang

a.Bagian Produksi

1). Membuat surat permintaan bahan baku sesuai kebutuhan sebanyak 2 rangkap.

2). Bagian produksi menerima Surat Pengiriman Bahan Baku (SPBB) beserta bahan baku dari bagian gudang.

3). Bagian produksi memproduksi bahan baku menjadi barang jadi, kemudian mengiring barang jadi ke bagian gudang.

b. Bagian Gudang

1). Menerima surat permintaan bahan baku dari bagian produksi.

2). Berdasarkan SPBB bagian gudang membuat SPBB rangkap 2. Lembar ke-1 dikirm ke bagian produksi beserta bahan baku yang diminta dan lembar ke-2 disimpan sebagai arsip.

3). Berdasarkan SPBB, bagian gudang membuat bukti permintaan dan pengeluaran bahan baku gudang rangkap 2.

4). Berdasarkan bukti permintaan dan pengeluaran bahan baku, bagian gudang membuat laporan persediaan bahan baku rangkap 2 .

5). Berdasarkan barang jadi, bagian gudang membuat laporan barang jadi rangkap 2 .

c. Bagian Akuntansi

1). Menerima laporan persediaan bahan baku, bukti permintaan dan pengeluaran bahan baku gudang, dan laporan barang jadi, bagian akuntansi membuat laporan permintaan dan pengeluaran barang gudang rangkap 2 .

d. Manajer

1). Menerima laporan permintaan dan pengeluaran barang gudang.

\section{Sistem Pencatatan Persediaan}

Sistem akuntansi persediaan bertujuan untuk mencatat setiap jenis persediaan yang ada di gudang. Sistem ini berhubungan erat dengan sistem penjualan, sistem retur penjualan, sistem pembelian, sistem retur pembelian dan sistem akuntansi biaya produksi (Wiratna, 2015:131).

Ada dua sistem yang digunakan untuk mencatat persediaan, yang masing-masing mempengaruhi nilai persediaan. Dua sistem tersebut adalah sebagai berikut.

1.Sistem Fisik/Periodik

Pencatatan persediaan dalam metode ini hanya dilakukan pada akhir periode akuntansi melalui ayat jurnal penyesuaian.

2.Sistem Perpetual

Menurut Sugiono yang dikutip oleh Anwar dan Karamoy (2014), pada sistem ini setiap melakukan pembelian barang dagangan berarti menambahkan (mendebet) perkiraan persediaan dan sebaliknya mengurangi (mengkredit) apabila terjadi transaksi penjualan.

\section{Metode Penentuan Harga atau Biaya Pokok Persediaan}

Penentuan harga perolehan persediaan dan harga pokok penjualan dilakukan berdasarkan asumsi arus biaya (cash flow assumption) bukan berdasarkan asumsi arus fisik persediaan. Terdapat beberapa metode penentuan harga perolehan dan harga pokok penjualan 
yang dapat diaplikasikan. Dalam Syakur (2015:151), metode-metode tersebut antara lain sebagai berikut.

1.Metode Rata-rata Sederhana

Penggunaan metode ini mengharuskan dilakukannya penandaan (identifikasi) terhadap setiap barang dagangan yang dibeli.

2. Metode Masuk Pertama Keluar Pertama (MPKP)

Metode ini biasa juga disebut sebagai metode FIFO (First In First Out). Metode ini dikembangkan berdasarkan asumsi bahwa persediaan barang dagangan yang pertama dibeli adalah persediaan yang pertama harus dijual (the first merchandise purchased is the first merchandise sold).

\section{Metode Masuk Terakhir Keluar Pertama (MTKP)}

Metode penentuan harga perolehan persediaan ini biasa pula disebut sebagai metode LIFO (Last In First Out). Metode ini dikembangkan berdasarkan asumsi bahwa barang dagangan yang terakhir dibeli adalah barang dagangan yang pertama dijual (the last merchandise purchased is the first merchandise sold).

4. Metode Rata-rata Tertimbang

Barang-barang yang dipakai untuk produksi atau penjualan akan dibebani harga pokok ratarata. Perhitungan harga pokok rata-rata dilakukan dengan cara membagi jumlah harga perolehan dengan kuantitasnya.

\subsection{Pengendalian Internal}

\section{Pengertian Penendalian Internal}

Widya (2013) menyatakan bahwa, "pengendalian intern harus dilaksanakan seefektif mungkin dalam suatu perusahaan untuk mencegah dan menghindari terjadinya kesalahan, kecurangan, dan penyelewengan.

\section{Tujuan Pengendalian Internal}

Suatu perusahaan akan berhasil dengan baik apabila dari setiap perusahaan itu telah ditetapkan dan direncanakan oleh semua anggota yang ikut terlibat dalam suatu perusahaan baik tujuan maupun komponen-komponen yang mempengaruhi kegiatan tersebut.

\section{Unsur-unsur Pengendalian Internal}

Unsur-unsur pengendalin internal menurut Mulyadi terdiri dari empat unsur sebagai berikut.

1. Struktur organisasi yang memisahkan tanggung jawab fungsional secara tegas.

2. Sistem wewenang dan prosedur pencatatan yang memberikan perlindungan yang cukup terhadap kekayaan, utang, pendapatan dan biaya.

3. Praktik yang sehat dalam melaksanakan tugas dan fungsi setiap unit organisasi.

4. Karyawan yang mutunya sesuai dengan tanggungjawabnya.

\section{Prosedur Pengendalian Internal}

Secara luas prosedur pengendalian internal pada persediaan meliputi pengarahan arus dan penanganan barang mulai dari penerimaan, penyimpanan, sampai saat barang-barang yang siap untuk dijual.

\section{METODE PENELITIAN}

\subsection{Jenis Penelitian dan sumber data}

Jenis penelitian ini adalah menggunakan penelitian kualitatif yaitu data yang disajikan dalam bentuk deskriptif yang bukan berupa angka dan sifatnya menunjang data kuantitatif sebagai keterangan.

Sumber data yang dipergunakan dalam penulisan ini berasal dari, data primer, yaitu data yang diperoleh dari hasil observasi dan wawancara langsung dengan pimpinan serta karyawan dari PT. Fajar Indah Kusuma Kabupaten Tolitoli. Dan data sekunder, yaitu data yang diperoleh berupa dokumen-dokumen serta informasi tertulis lainnya yang ada hubungannya dengan penelitian ini. 


\subsection{Teknik Pengumpulan Data}

Teknik pengumpulan data yang dilakukan dalam penelitian ini adalah sebagai berikut: 1.Obsevasi atau pengamatan, yaitu teknik pengambilan data dan informasi yang relevan, yang dilakukan dengan cara mengamati secara langsung semua proses kegiatan yang terjadi dalam usaha ini.

2.Wawancara, yaitu teknik pengumpulan data dengan cara melakukan tanya jawab secara langsung sehingga diperoleh data dan informasi yang relevan dan memadai.

3.Dokumentasi, yaitu mengumpulkan data dan informasi dari sumber-sumber tertulis melalui buku-buku, jurnal, dan informasi dari internet dengan melakukan penelitian terhadap catatan atau dokumen yang ada seperti sejarah perusahaan, struktur organisasi dan prosedur sistem akuntansi persediaan serta dokumen pendukung lainnnya yang dijadikan pelengkap dan referensi penelitian.

\subsection{Metode Analisis}

Metode analisis yang digunakan untuk membahas permasalahan dalam penelitian ini adalah analisis deskriptif. Untuk lebih jelasnya, langkah-langkah yang ditempuh dalam upaya mengevaluasi sistem informasi akuntansi persediaan pada PT. Fajar Indah Kusuma Kabupaten Tolitoli Provinsi Sulawesi Tengah adalah sebagai berikut :

1.Mengetahui struktur organisasi PT. Fajar Indah Kusuma serta tugas masing-masing.

2.Mengidentifikasi informasi-informasi yang diperlukan manajemen dari jasa yang ditawarkan kepada pelanggan. Lebih khusus pada persediaan pelumas.

3.Melakukan perbandingan antara pemisahan fungsi yaitu dengan cara mengidentifikasi unsur-unsur pada setiap fungsi yang terjadi dilapangan.

4.Berdasarkan hasil penelitian dapat dirancang suatu sistem informasi yang dibutuhkan oleh pihak manajemen maupun pihak luar.

5.Menarik suatu kesimpulan serta dapat memberikan saran dan masukan tentang sistem informasi akuntansi persediaan pada PT. Fajar Indah Kusuma.

\section{HASIL ANALISIS DAN PEMBAHASAN}

\subsection{Hasil analisis}

\section{Sistem Informasi Akuntansi Persediaan Pada PT. Fajar Indah Kusuma}

Sistem akuntansi persedian yang digunakan pada PT. Fajar Indah Kusuma masih bersifat manual. Berikut ini merupakan sistem informasi akuntansi yang digunakan pada PT. Fajar Indah Kusuma :

a. Fungsi-fungsi yang terkait dalam sistem informasi akuntansi persedian pada PT. Fajar indah kusuma :

1)Pemilik

Dalam sistem informasi akuntansi pemilik bertugas untuk melakukan pembelian dan transaksi lain yang berhubungan dengan pemasok.

2)Administrasi

Tugas bagian administrasi dalam sistem informasi akuntansi persediaan adalah melakukan pencatatan laporan yang berhubungan dengan pemasok.

3)Gudang

Bagian gudang bertugas untuk mengelolah persediaan barang dagang yang ada di perusahaan, serta mencatat mutasi barang yang keluar dan masuk gudang.

4)Teknisi dan Transportasi

Teknisi dan Transportasi bertugas untuk merakit barang dagang yang memerlukan perakitan. Tugas teknisi dan transportasi selanjutnya adalah mengantarkan barang dagang kepada konsumen.

B. Dokumen-dokumen yang berkaitan dalam Sistem Informasi Akuntansi Persediaan pada PT. Fajar indah Kusuma : 
1)Surat Order Pembelian

Dokumen yang digunakan untuk melakukan order barang kepada pemasok.

2)Nota pembelian

Nota pembelian adalah nota yang digunakan dalam mencatat transaksi pembelian. Dokumen ini diperoleh perusahaan dari pemasok, jadi format nota pembelian berbeda-beda tergantuk pemasok, namun didalam biasanya memuat kuantitas barang.

3)Surat Pengantaran Pengiriman

Surat pengantaran pengiriman adalah surat yang digunakan untuk mengecek jumlah barang yang dikirim, apakah sudah sesuai dengan barang yang telah dipesan oleh pemesan.

4)Surat Terima Barang

Surat terima barang adalah surat yang digunakan sebagai bentuk tertulis nyata /bukti untuk menghindari hal-hal yang tidak diinginkan seperti barang yang hilang.

C. Catatan-catatan yang terkait dalam Sistem Informasi Akuntansi Persediaan pada PT. Fajar indah Kusuma :

1)Catatan pembelian

Catatan pembelian di PT. Fajar Indah kusuma digunakan untuk mencatat transaksi pembelian setiap hari, dalam hal ini catatan pembelian ditulis dalam sebuah buku.

2)Rekapitulasi Persediaan

Rekapitulasi persediaan di PT. Fajar Indah Kusuma digunakan untuk mencatat semua persediaan pelumas. Di PT. Fajar Indah Kusuma rekapitulasi persediaan dicatat dalam sebuah catatan persediaan.

3)Kartu Persediaan

Catatan akuntansi ini digunakan untuk mencatat kuantitas dan harga pokok barang yang disimpan di gudang yang tercantum dalam kartu persediaan oleh bagian kartu persediaan, berdasarkan hasil penghitungan fisik persediaan

4)Kartu Gudang

Kartu gudang ini berfungsi sebagai identitas barang yang disimpan, untuk memudahkan pencarian barang dan sekaligus untuk mencatat mutasi kuantitas barang yang tercantum dalam kartu gudang yang diselenggarakan oleh bagian gudang, berdasarkan hasil penghitungan fisik persediaan.

Pengendalian Internal Dalam Sistem Akuntansi Persediaan Pada PT. Fajar Indah Kusuma

Sistem yang digunakan dalam pengendalian intern sistem pengendalian di PT. Fajar Indah Kusuma berdasarkan unsur-unsurnya sebagai berikut :

1)Organisasi

Perhitungan persedian barang dagang secara fisik pada PT. Fajar Indah Kusuma dilakukan oleh semua karyawan, baik itu keryawan yang ada di bagian gudang.

2)Sistem Otoritas dan Prosedur Pencatatan.

Rakapitulasi persediaan barang dagang dibuat dalam sebuah catatan persediaan kemudian disimpan dan digunakan sebagai arsip perusahaan.

3)Praktik Yang Sehat

Pengelolaan persediaan barang dagang pada PT. Fajar Indah Kusuma telah menggunakan kartu persediaan. Pencatatan persediaan barang dagang juga dilakukan dalam rekapitulasi persediaan barang dagang. Perhitungan persediaan barang dagang dilakukan satu bulan sekali.

\section{Prosedur Sistem Informasi Akuntansi Persedian Pada PT. Fajar Indah Kusuma}

Secara luas prosedur sistem informasi akuntansi pada persediaan meliputi pengarahan arus dan penanganan barang mulai dari penerimaan, penyimpanan, sampai saat barangbarang yang siap untuk dijual. Prosedur sistem informasi akuntansi persediaan yang dijalankan oleh PT. Fajar Indah Kusuma adalah sebagai berikut : 
1. Prosedur Pembelian / Order pada PT. Fajar Indah Kusuma kepada PT. Pertamina Lubrikants :

a. Melakukan order via telfon, maka akan kluar perintah penyetoran barang.

b. Membuat slip penyetoran / OPBS (operational system), dan SPSH (Kode bayar kode identitas yang dibayar).

c. Melakukan pembayaran dibank.

d. Secara otomatis kode SPSH masuk di sistem pertamina, menunggu kiriman, barang yang sudah di siapkan / di setujui

e.Barang diantar oleh pertamina lubrikants melalui transportir pelumas ke gudang pembeli PT. Fajar Indah Kusuma.

2.Bagian Gudang

a.Mengecek barang, mencocokan surat jalan dengan surat tanda terima barang

b.Setelah setoran dicek / dicocokan dari bukti pembayaran dengan OPBS (surat pengantar pengiriman barang) maka barang dibongkar

c.Setelah dibongkar, dicocokan dari surat pengiriman barang dengan barang factual / barang yang ada (cross cek)

d.Setelah dicocokan, bagian gudang mentandatangani surat berita acara serah terima (BAST)

3.Bagian Administrasi :

a.Memasukan semua data pembelian oli ke sistem pertamina Mforse, pakai sistem manual

b.Mengarsipkan SPP dari bagian pembelian

c.Membuat surat SPP dan BAST

4.Bagian penjualan

Terdapat 2 bagian penjualan :

1. Industri, kemasan dalam bentuk drum

a. Buat P.O dari pembeli

b. Perusahaan buat penawan harga, mengenai oli, jenis oli, metode pembayaran, harga, barang diantar atau tidak, disesuaikan dengan kesepakatan bersama

c. Jika sudah sepakat, maka barang akan diantar dengan menyetorkan BAST dan SPP ( Surat Pengantar Pengiriman). Jika barang tidak diantar / diambil sendiri maka pembeli akan menerima BAST

2. Retail, kemasan dalam bentuk kemasan dos

a. Sales jalan menggunakan sistem Mforce

b. Sales ke kantor

c. Perusahaan buat SPP dan BAST.

\subsection{Pembahasan}

\section{Sistem Informasi Akuntansi Persediaan Yang Diterapkan Pada PT. Fajar Indah} Kusuma

Berdasarkan hasil penelitian, sistem informasi akuntansi persediaan yang diterapkan di PT. Fajar Indah Kusuma masih bersifat manual dan sederhana, perusahaan kecil dan menengah cenderung masih menggunakan sistem informasi akuntansi yang manual dan sederhana.

Sistem persediaan yang diterapkan di PT. Fajar Indah Kusuma masih memeiliki kelemahan terutama dalam hal kinerja dalam menghasilkan informasi persediaan dan efisiensi. Untuk mengatasi kelemahan yang terdapat pada sistem tersebut, salah satu solusi yang dapat dilakukan oleh PT. Fajar Indah Kusuma adalah dengan mengganti sistem lamanya dengan sistem yang baru. Sistem yang baru tersebut berupa sistem informasi akuntansi persediaan yang sederhana tapi dapat lebih lagi meningkatkan kinerja dan mengatasi kelemahan sistem yang lama. 


\section{Pengendalian Internal Dalam Sistem Akuntansi Persediaan Pada PT. Fajar Indah Kusuma}

Sistem pengendalian internal di PT. Fajar Indah Kusuma masih lemah. Hal ini disebabkan karena perusahaan ini masih belum melakukan standar perusahaan yang tepat. Metode penghitungan persediaan masih dilakukan oleh semua karyawan, termasuk bagian gudang yang mengelola persediaan. Jika karyawan bagian gudang yang melakukan penghitungan persediaan, sama saja karyawan tersebut mengevaluasi pekerjaannya sendiri. Pemilik hanya cukup mengetahui bahwa rekapitulasi persediaan telah selesai dibuat dan tanpa melakukan pengecekan lebih lanjut. Perusahaan seringkali mengacaukan dan mengabaikan fungsi masing-masing bagian sehingga pengendalian internal menjadi lemah.

\section{Prosedur Sistem Informasi Akuntansi Persedian Pada PT. Fajar Indah Kusuma}

Prosedur-prosedur yang digunakan dalam sistem informasi akuntansi persediaan di PT. Fajar Indah Kusuma terdiri dari prosedur penerimaan barang, penyimpanan barang, dan pengeluaran barang. Pembuatan catatan dilakukan berdasarkan dokumen transaksi yang ada.

\section{KESIMPULAN DAN SARAN}

\subsection{Kesimpulan}

1. PT. Fajar Indah Kusuma belum menerapkan sistem informasi akuntansi persediaan secara mamadai, karena terdapat beberapa kekurangan pada bagian pemisah fungsi khususnya pada bagian gudang dimana perusahaan hanya memiliki satu karyawan yang merangkap pekerjaan yang dapat beresiko menimbulkan kekeliruan dan pengendalian internal yaitu masih dilakukannya perhitungan persediaan barang oleh semua karyawan termaksud bagian gudang, yang beresiko melakukan manipulasi data karena tidak adanya pengawasan.

\subsection{Saran}

Saran yang dapat diberikan oleh peneliti pada PT.Fajar Indah Kusuma adalah :

1.PT. Fajar Indah kusuma sebaikanya menambah karyawan khususnya pada bagian gudang, agar pemisah fungsi dapat berjalan sesuai standar.

2.PT. Fajar Indah Kusuma sebaiknya memperbaiki sistem pengendalian internal pada perusahaan agar penghitungan persediaan dan fungsi masing-masing bagian pada perusahaan dapat berjalan secara efisien.

\section{DAFTAR PUSTAKA}

Agyemang, Faizer, Agyei, Nketiah dan Mensah (2014), "Computerised Accounting Information Systems: Lessons in State-Owned Enterprise in Developing Economies", Journal of finance and Management in Public Servces Kwame Nkrumah University of Science and Technology, 12 (1)

Alannita, Ni Putu dan I Gusti Ngurah Agung Suaryana, (2014), "Pengaruh Kecanggihan Teknologi Informasi, Partisipasi Manajemen, dan Kemampuan Teknik Pemakai Sistem Informasi Akuntansi Pada Kinerja Individu",E-Jurnal Akuntansi Universitas Udayana, 6 (1)

Bednar dan Hopwood, 2010. “Accounting Information Sytme $10^{\text {th }}$ ed”. International Edition, Pearson Education, Inc

Bodnar, G. H., dan William S. Hopwood (2012) Accounting Information System (11 ed). Penerbit : Pearson Education, United States of America

Calvasina, Mysore, Richard, Eugene dan Gerald (2012),'Information Technology Driven Restructuring of Financial/Managerial Accounting Report,"Issues Of Information Systems 13 (1): 232-239 
Chandra Gregorius dan Adriana Dadi (TM Books) (2015), Sistem Informasi Akuntansi Konsep dan Penerapan. Penerbit: CV. Andi Offset, Yogyakarta.

Daoud, Hazar dan Triki Mohamed (2013), "Accounting Information System in an ERP Environment and Tunisian Firm Perfomance", The International Journal of Digital Accounting Research Universitas Sfax Tunisia, 13:1-35.

Ester, 2013. "Penerapan Akuntansi Persediaan Untuk Perencanaan dan Pengendalian". Gunawan, 2010. "Informasi Akuntansi Pembelian dan Persediaan PT. Poli (antrindo nusa)".

Ikatan Akuntan Indonesia (Revisi 2010), Pernyataan Standar Akuntansi Keuangan,Penerbit: Salemba Empat, Jakarta

Indrawan, Rully dan Raden P. Yaniawati (2014), Metodologi Penelitian, Penerbit: PT. Refika Aditama, Bandung

Jofiyanto V.M. "Sistem Informasi Akuntansi Berbasis Komputer". Buku Satu Konsep Dasar dan Komponen, Edisi I BPFE Yogyakarta.

Mardi, M.Si. 2011. "Sistem Informasi Akuntansi”. Penerbit : Ghalia Indonesia, Bogor.

Midjan La dan Susanto (2011 : 150). "Sistem Informasi Akuntansi I, Lingga Jakarta" 